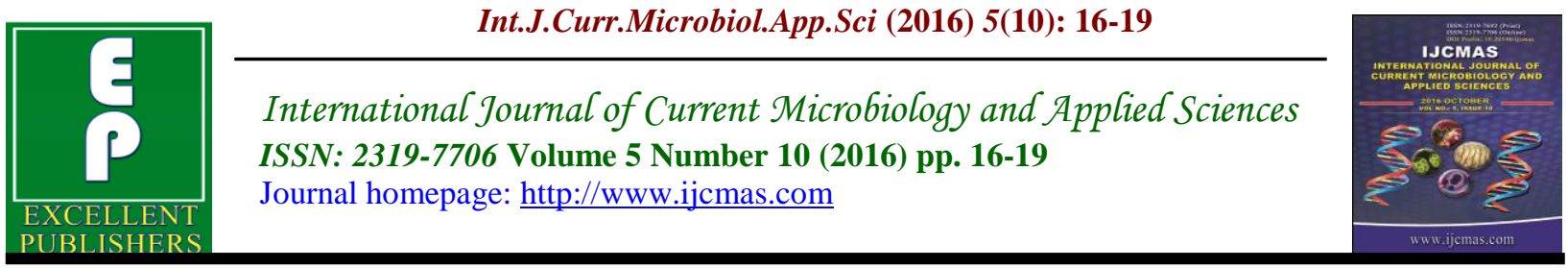

Original Research Article

http://dx.doi.org/10.20546/ijcmas.2016.510.003

\title{
Antibiotic Susceptibility of Uropathogenic E.coli Isolates from Hospitalized Patients in Warangal City
}

\author{
M. Punnam Chander* \\ Department of Medical Microbiology \& Molecular Biology, Regional Medical Research Centre \\ (Indian Council of Medical Research), Port Blair -744103, Andaman and Nicobar Islands, India \\ *Corresponding author
}

\begin{tabular}{|c|c|}
\hline & A B S T R A C T \\
\hline $\begin{array}{l}\text { E.coli, } \\
\text { Antibiotic } \\
\text { resistance, } \\
\text { Urinary Tract } \\
\text { Infection (UTI). }\end{array}$ & \multirow{3}{*}{$\begin{array}{l}\text { Urinary tract infection (UTI) is increasingly rising due to the development of drug } \\
\text { resistance of causative pathogens against commonly prescribed antibiotics. } \\
\text { Escherichia coli is the leading pathogen causing urinary tract infections. In the } \\
\text { present study we attempted to examine the prevalence of uropathogens and } \\
\text { antibiogram profiles of E. coli isolates. A total of } 89 \text { urine samples were processed } \\
\text { for culture sensitivity testing. Isolation of the organisms was done by inoculation of } \\
\text { sample on Nutrient and MacConkeyagar. Out of } 89 \text { samples were processed, } 70 \\
\text { organisms were isolated from urine which includes Escherichia coli ( } 45) \text {, } \\
\text { Klebsiella pneumoniae (13), Pseudomonas aeruginosa (08), and Entrococcus spp. } \\
\text { (04). Antibiotic sensitivity was carried out using Muller Hinton agar medium by } \\
\text { disc diffusion Method. E.coli is most common organism ( } 64.3 \%) \text {. High resistance } \\
\text { levels were detected against gentamicin }(91.11 \%) \text { while Nitrofurantoin recorded } \\
\text { the least resistance levels }(13.33 \%) \text { among the E. coli isolates. }\end{array}$} \\
\hline Article Info & \\
\hline $\begin{array}{l}\text { Accepted: } \\
\text { 12 September } 2016 \\
\text { Available Online: } \\
10 \text { October } 2016\end{array}$ & \\
\hline
\end{tabular}

\section{Introduction}

Urinary tract infection (UTI) which is defined as presence and active multiplication of microorganisms within the urinary tract is one of the commonest bacterial infections seeking treatment in clinical practice (Magoha, 1997). Escherichia coli is the leading pathogen causing urinary tract infections and is among the most common pathogens causing blood stream infections, wounds and other complications in humans (Kashef et al., 2010; Gebre-Sellassie et al., 2007; Khan et al., 2010).

Microorganisms causing UTI vary in their susceptibility to antimicrobials from place to place and time to time. The present study was designed to identify the etiological agents of UTI in males and females of different age groups and to investigate the antibiotic susceptibility profile of uropathogenic E.coli isolates against locally available antibiotics commonly prescribed by the physicians.

\section{Materials and Methods}

Urine specimens were collected from 89 patients of all ages suffering from UTIs for this study at microbiology laboratory section of Mahatma Gandhi Memorial Hospital, 
Warangal. For bacteriological analysis, Nutrient Agar and MacConkey agar media plates were used. With a calibrated loop of 3 $\mathrm{mm}$ diameter, the appropriately labelled media petriplates were streaked aseptically with $0.01 \mathrm{ml}$ urine sample. The plates were then incubated at $37^{\circ} \mathrm{C}$ for 18 hrsaerobically. Bacterial identification was done by Gram staining and standard biochemical tests. Bacterial susceptibility to eight antibiotics towards pathogenic bacteria using Agar disc diffusion assay as described previously (Bauer, 1966). At the end of incubation period, inhibition zones for individual antimicrobial agents formed around the discs were measured in millimetre were translated into susceptible, intermediate and resistant categories (Ferraro, 2001).

\section{Results and Discussion}

Out of 89 urine specimens from UTI affected, $73 \%$ were female and $27 \%$ were male. Women in the age group 16 - 45 years are most likely to suffer from UTI. Among the elderly, after 45 years males became more prone to UTI (Fig. 1). The drug resistance and sensitivity profile of the organism showed that all the bacterial isolates were resistant against commonly used antibiotics, e.g. Gentamycin, Ampicillin, Ofloxacin and Ciprofloxacin (Fig. 2).

Moreover, more than $60 \%$ of the organisms showed resistance against Gentamycin, Ampicillin, Ofloxacin, and Ciprofloxacin. All antibiotics used in this study with the exception of Nitrofurantoin and Amikacin showed increasing resistance rates against the E.coli. The increased accessibility of antibiotics in shops and open markets is probably an important factor in antibiotic resistance worthy of consideration. Discontinuation of treatment due to negligence of patient or unavailability of drugs also develops antibiotic resistance (Laxminarayan et al., 2006). The results of this study therefore support the use of either Nitrofuranton or Amikacin as a reasonable choice for empiric therapy in uncomplicated UTI, particularly in the hospitalized setting.

Table.1 Drug sensitivity profile of E.coli isolates against commonly used antibiotics

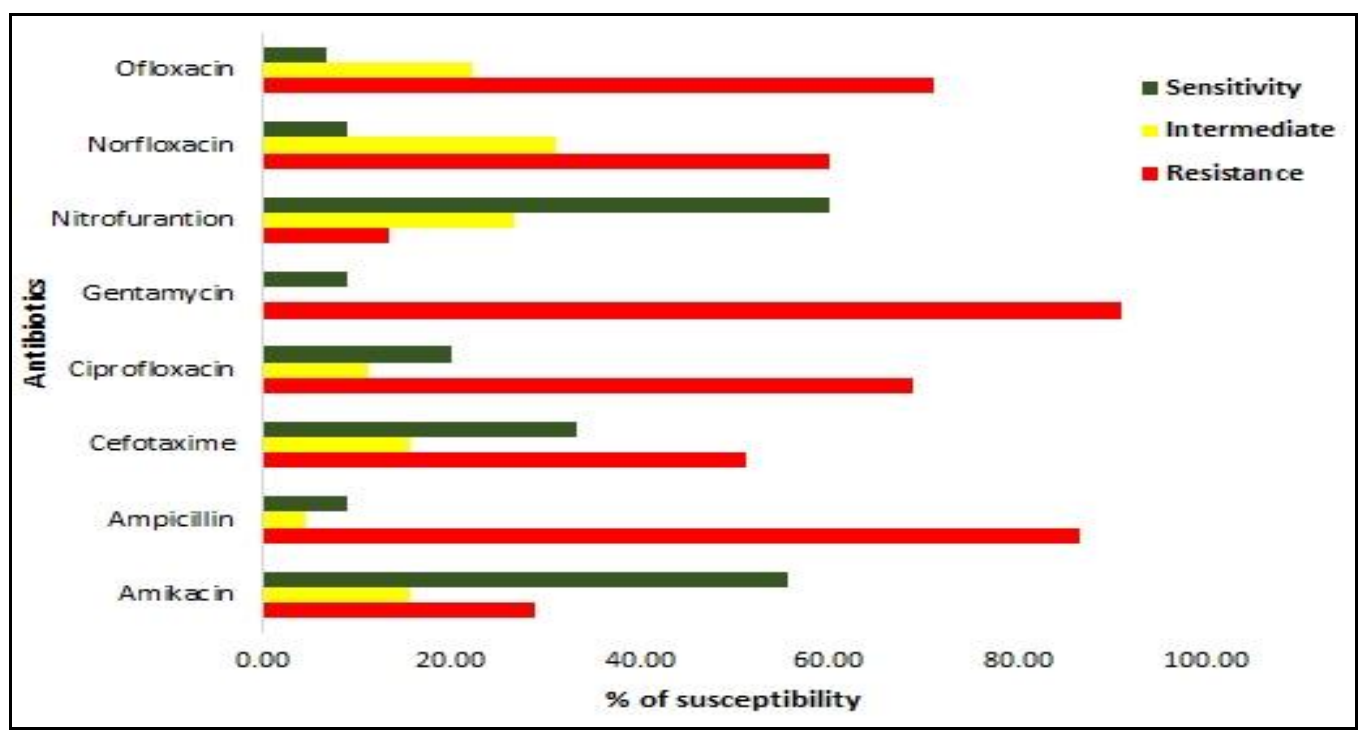


Fig.1 Age-wise distribution

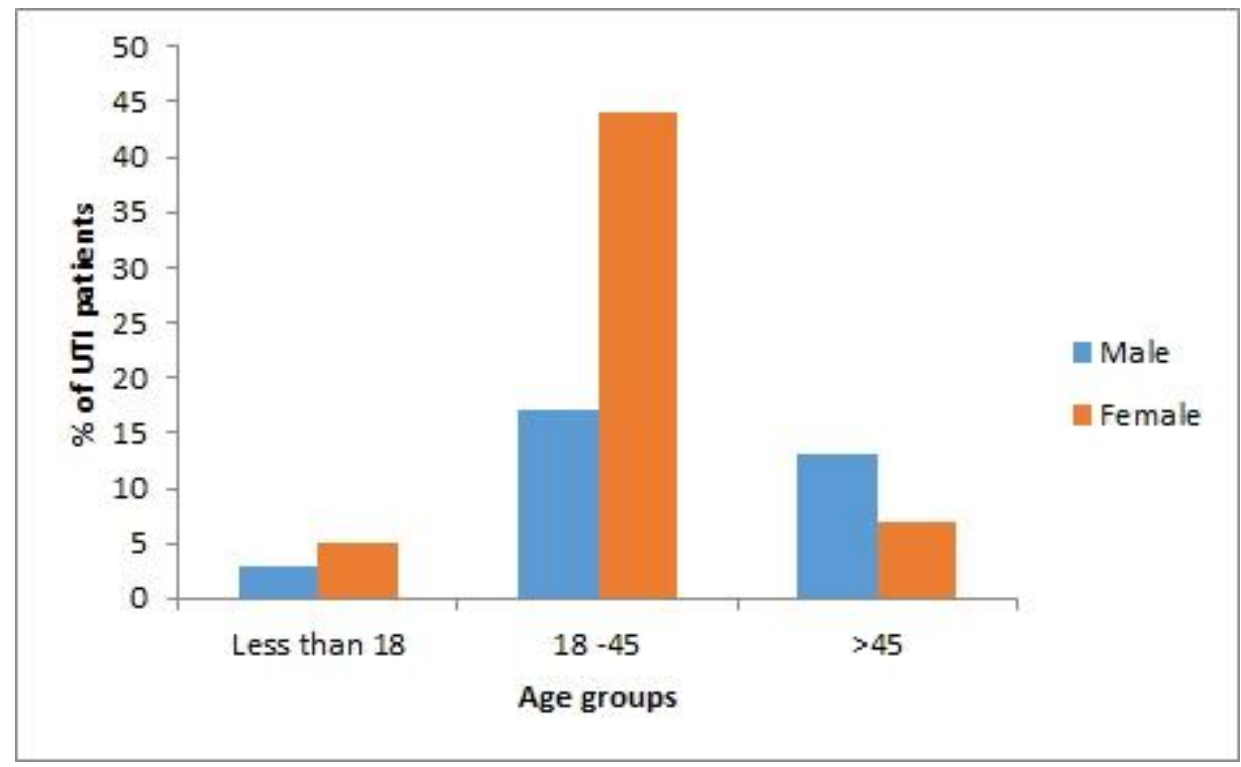

The majority of the pathogenic microorganisms isolated in this study belonged to the Enterobacteriaceae family. E. coli was identified as the most common causative agent of UTIs in both male and female patients. Since E. coli caused the majority of UTI, the emergence of antibiotic resistant $E$. coli thus presents a challenge for urinary tract health management. In this study, E. coli also showed high resistance against Gentamycin (91.11\%) and Ampicillin (86.67\%). Therefore, these drugs should no longer be prescribed as initial empirical therapy in this region.

In conclusion, the results of this study show high rates of antimicrobial resistance to Gentamycin, Ampicillin, Oflaxacin, Ciprofloxacin and Norfloxacin. Nitrofurantoin, Amikacin and Cefotaxime are considered appropriate for empirical treatment of $E$. coli in the study area. Periodic monitoring of antimicrobial susceptibility in the hospital settings is recommended.

\section{Acknowledgement}

Author thank Dr. M.V. Ramanama, Professor \& Head, Department of
Microbiology, Kakatiya Medical College, Warangal for guiding the M.Sc. dissertation study. Author also thankful to Dr.Gopal Reddy, HOD, Department of Microbiology, Osmania University.

\section{References}

Bauer, A.W., W.M.M. Kirby, J.C. Sherris and M. Tierch. 1966. Antibiotic susceptibility testing by a standardized single disc method. Amer. J. Clin. Pathol., 45(4): 493-496.

Biedenbach, D.J., Moet, G.J., Jones, R.N. 2004. Occurrence and antimicrobial resistance pattern comparisons among bloodstream infection isolates from the SENTRY Antimicrobial Surveillance Program (1997-2002). Diagnostic Microbiol. Infect. Dis., 50: 59-69.

Ferraro, M.J., W.A. Craig and M.N. Dudley. 2001. Performance standards for antimicrobial susceptibility testing NCCLS informational supplement. 11th ed. NCCLS, Pennsylvania, USA.

Gebre-Sellassie, S. 2007. Antimicrobial resistance patterns of clinical bacterial isolates in southern Ethiopia. Ethiop. 
Med. J., 45(4): 363-370.

Kashef, N., Djavid, G.E., Shahbazi, S. 2010. Antimicrobial susceptibility patterns of community-acquired uropathogens in Tehran, Iran. J. Infections in Developing Countries, 4(4): 202-206.

Khan, N.A., Saba, N., Abdus, S., Ali, A.Q. 2002. Incidence and antibiogram patterns of $E$. coli isolates fromvarious clinical samples from patients at $\mathrm{NIH}$ Islamabad. Pak. J. Biol. Sci., (1): 111113.

Laxminarayan, R., Bhutta, Z., Duse, A., et al. 2006. Drug Resistance. In: Jamison, D.T., Breman, J.G.,
Measham, A.R., et al., editors. Disease Control Priorities in Developing Countries.2nd edition. Washington (DC): The International Bank for Reconstruction and Development / The World Bank. Chapter 55.Copublished by Oxford University Press, New York.

Magoha, G.A.O. 1997. Nosocomial infections of the urinary tract: patterns of antibiotic use and drug resistance. East Afr. Med. J., 74: 190-193.

\section{How to cite this article:}

Punnam Chander, M., 2016. Antibiotic Susceptibility of Uropathogenic E.coli Isolates from Hospitalized Patients in Warangal City. Int.J.Curr.Microbiol.App.Sci. 5(10): 16-19. doi: http://dx.doi.org/10.20546/ijcmas.2016.510.003 